\title{
A Framework to Inform Protective Support and Supportive Protection in Child Protection and Welfare Practice and Supervision
}

\author{
Caroline McGregor ${ }^{1, *(1)}$ and Carmel Devaney ${ }^{1,2}$ (1) \\ 1 UNESCO Child and Family Research Center, The National University of Ireland, H91 C7DK Galway, Ireland; \\ carmel.devaney@nuigalway.ie \\ 2 School of Political Science and Sociology, The National University of Ireland, H91 C7DK Galway, Ireland \\ * Correspondence: caroline.mcgregor@nuigalway.ie
}

Received: 1 March 2020; Accepted: 29 March 2020; Published: 7 April 2020

\begin{abstract}
In this article, our intention is to provide an in-depth framework to inform the management of the inevitable complexity of day-to-day practice and supervision in child protection and welfare. It is based on what is now well evidenced about child protection and welfare literature in relation to risk, relationships, family support, supervision, and professional development. Using Ireland as a case example for illustration and application, we introduce an emerging framework based on a dualism of 'protective support and supportive protection' developed in previous work. We avail of Bronfenbrenner's bio-ecological framework and network theories to progress this ongoing 'work in progress' to inform social work and social care practice and supervision in a global context as and where appropriate. We emphasize the importance of context specific approaches, the relevance of range of actors, practitioner and supervisor expertise through experience, and proactive partnership based engagement with children, families, and relevant communities in all aspects of service delivery, including evaluation. We reflect on the challenges and possible obstacles to how such a framework can inform practice and supervision. We argue that practitioners can best activate and apply the framework using a practice research approach.
\end{abstract}

Keywords: child abuse; child protection and welfare; public protection; family support; bio-ecological; networks and networking

\section{Introduction}

\subsection{Setting the Scene}

"The closer we can get to ensuring that children and families, no matter what point they come into contact with 'the system' or 'the state,' are responded to in a manner that promotes strengths, offers partnership working, supports while it asserts and prosecutes as needed to protect, the more likely we are to achieve the goal of reducing abuse and neglect and enhancing family well-being" (McGregor and Devaney 2020, p. 284).

In this article, using Ireland as a case example, we propose a framework of protective support and supportive protection that can be used to inform practice and supervision in different global contexts to complement existing approaches. We present this as a conceptual paper to inform supervision and practice development. We propose that a practice research approach can advance the proposed framework further.

This first section provides a commentary on the current literature relating to the relationship between child protection and family support showing a complex range of considerations for practitioners to be aware of. We then consider the Irish context as a specific illustration of child welfare and protection 
practice. In the results section, we set out our framework for protective support and supportive protection as a way to manage the complex demands of supporting and protecting children, young people, and families. To advance this, we consider the relationship between family support and child protection within the context of Bronfenbrenner and Morris (2006) bio-ecological approach. In particular, we avail of their use of PPCT (person, process, context, and time) to articulate strengths and challenges in supporting and protecting families within the Irish system. We combine this with relevant network theories to inform practice. To assist in the application to practice, we have developed tools to illustrate how this can be used to inform practice development and supervision conversations (see Appendices A-C). We propose that the next step is to implement this framework using a practice research approach (Appendix D) that enables the use of the framework to influence and be influenced by day-to-day practice.

There are multiple stories to tell about child protection and family support with numerous publications that inform how the current challenges in child protection can be addressed (e.g., Parton 2015a, 2015b, 2015c). This includes the importance of relational social work and growing evidence of a link between the strength of partnership/collaboration with parents and better outcomes/reductions in child maltreatment. There is concrete evidence of the dominance of social factors of inequality, poverty, and disadvantage as contributing factors to child neglect and child welfare concerns (Bywaters et al. 2018; Morris et al. 2018). The impact of adverse childhood experiences (ACES's) (Spratt et al. 2019; Joy and Beddoe 2019), trauma (Lotty et al. 2020), difficulties with disorganized attachment (Shemmings and Shemmings 2011), and working with parents with severe and enduring mental illness (Killion 2020) are significant contemporary concerns. We have advanced knowledge, research, and practice guidance relating to assessment, risk, and decision making (McCafferty and Taylor 2020). A welcomed emphasis on the wider social conditions of child welfare in research (Parton 2014; Featherstone et al. 2018), public health approaches to child protection (Lonne et al. 2019; Canavan et al. 2019), and community development approaches (Liebenberg and Hutt-Macleod 2017) is evident. Sophisticated differential analysis of different aspects of child abuse and neglect are widely available such as child sexual exploitation (Pearce 2019), child to parent violence (Coogan 2017), child protection and domestic violence (Overlien and Holt 2019; Holt et al. 2018; Buckley 2018), and digital and on-line abuse (McAlinden 2012). A long-standing concern about how to intervene sensitively with different cultures and differences within cultures continues (e.g., Bartley and Beddoe 2018; Ferguson et al. 2018; Munford and O'Donoghue 2019) which has helped to orient global practice towards greater awareness of cultural humility (Mafile'o 2019), alongside other related concepts of cultural competence, awareness, and sensitivity. This adheres well with principles of partnership and participation now embedded in child protection practices (Bell 1999; Slettebø 2013). The need for strategic leadership that takes account of the complexity of child protection practice (e.g., Morrison 2010) and the possibility of child protection social work transforming from a siloed to a networked profession (Frost 2017) are important further considerations. Gradually, the voice of service users and those who have experienced services is gaining more ground in literature relating to practice (e.g., Buckley et al. 2011; Brown 2019) and education (Tanner et al. 2017; Sapouna 2020). Further co-construction of theory and practice to combine intellectual and theoretical constructs with evidence, data, and practice wisdom is clearly required. So too is a critical appraisal of an overly technical application of practice models and a recognition of the complexity and systemic nature of child welfare concerns and necessary interventions.

While we have a strong body of global evidence, the challenge of responding to the complex field of child welfare and protection remains ongoing. Despite many publications and approaches on child protection internationally, it is clear that child abuse and neglect—or child maltreatment—is still a major social problem that authors such as Parton discussed in work focused on child protection social work and social systems (e.g., Parton 1991, 2014). Ongoing critiques of practice, especially within the legal domain and in high profile tragedies, diminishes public and media confidence in the capacity of systems and professionals working within them to respond appropriately, neither over-interfering with 
family life nor being so laissez-faire that children are left in harmful and dangerous living conditions (Gibbons 2010). And, particularly relevant for this paper, the relationship between family support and child protection remains a complex and evolving one across many jurisdictions (see, Gilbert et al. 2011; Merkel-Holguin et al. 2019; Connolly and Katz 2019).

It can be difficult to avoid a pessimistic perspective that implies the problem of child abuse and neglect, and responses to it, are not only "wicked" (Devaney and Spratt 2009) but also intractable and un-addressable and/or toxic (Wilkins 2012). There is concern in some jurisdictions that child protection is becoming too narrowly focused and separated from wider discourses of social work (Higgins 2017). However, there is much evidence in literature also to show that optimism can be found in the increased visibility of practice-led research (Satka 2020) and more diverse indigenous perspectives which are potentially transformative (Libesman 2004; Bartley and Beddoe 2018). Increasingly perspectives from young people and families give clear and achievable guidance on what we need to do differently (e.g., Tierney et al. 2018). Even if not practiced as such, there is an overall conceptual shift towards recognizing that good child protection happens in the context of excellent prevention and family support (see Daro 2016, 2019; Devaney 2017) and that we need a stronger recognition of the need to address structural inequality and the problems that parents face (addiction, alcohol abuse, disability, etc.) (see, for example, Dolan and Nick 2017).

One important mechanism to maximize the potential for transformative practice is practice development and supervision (O'Donoghue 2019; McGregor 2016). Supervision and support with professional development is essential to support child protection and child welfare practice. Morrison's four stage model of supervision is commonly used which involves management, development, support, and mediation. McPherson's in-depth study in the Australian context shows that, in addition to Morrison's four functions, a fifth requirement was to provide safety for the workers (McPherson and MacNamara 2017). In recent years in Ireland, supervision has become more systematic and integrated into agency policy. Linked to supervision, registration requirements for social workers in place since 2012 in Ireland put greater emphasis on continuing professional development (CPD) (www.coru.ie). Workers are expected to develop their own individual learning plan that compliments a wider team and agency training and support program and access to evidence based program support (e.g., https://www.effectiveservices.org/work/tusla-empowering-practitioners-and-practice-initiative). We argue that the framework presented here can best be developed and applied through being used as a tool for supervision and continuing professional practice development.

\subsection{Introduction to Irish Child Protection and Welfare System}

Ireland has had a national child protection system since the Health Act 1970. Prior to that, it held statutory responsibility for some children in care (e.g., workhouses, county homes, and some children in industrial schools) and some children who were adopted. From 1970 to 2014, child protection and welfare services were part of a wider health and social services structure (see Burns and Caroline 2019). Ireland has always relied heavily on voluntary services to deliver core features of the system and child welfare, protection, and family support is made up of a network of statutory and voluntary/third sector and more recently private care organizations. In 2014, the Child and Family Agency (Tusla) was established as an independent statutory authority. In Q3 of 2019, the most recently reported data, there were 15,401 referrals for child protection and welfare to Tusla (from a child population of 1,251,796 as of Census 2016). Referrals are categorized as 'abuse and neglect' (emotional, physical, sexual, neglect) or 'welfare' (children and families in need). Overall, there is a $44 \%-56 \%$ split between referrals for 'abuse and neglect' and those categorized as 'welfare.' In addition to addressing 'welfare' (high need) through the child protection process, the system also provides a family support response focused on early intervention and prevention. In Q2 2019, 17,879 children were in receipt of family support services (Tusla Q3 report 2019). Tusla also provides alternative care to 5983 children (Tusla 2019). Care in Ireland is made up mostly of foster care - general and relative - accounting for $91 \%$ of all children. Tusla organizes its service on a continuum of help-support covering universal family support services to 
child protection interventions across four levels. A more integrated approach to support and protection is reflected especially with the mainstreaming of a program of prevention, partnership, and family support (PPFS) (see Malone and Canavan 2018). This article continues the themes developed to inform the Irish system which has resonance for child protection and welfare practice more widely.

\section{Results}

\subsection{Introduction}

In McGregor and Devaney (2020) we argued that for front line practice it is essential that those who have a responsibility to deliver support and protection to children and families "have the capacity to work in a manner that puts the child at the center and the skills and values to engage effectively in protective support work and supportive child protection" (p. 8). We argued that while family support and child protection are often treated separately, they have a shared history and a complimentary and reflexive relationship. We have further argued that the notion of 'protective support and supportive protection' can be used as an overarching conceptual framework for practice. This framework can inform the implementation of a range of support and protection practice models like, in Ireland, Meitheal and Signs of Safety. Our aim in this paper is to advance further this framework focused on the dualism of 'protective support and supportive protection' (McGregor and Devaney 2020) by setting it within a bio-ecological frame and emphasizing the importance of networking skills in this context. We are interested in how this work can inform practice development and supervision with child protection and welfare practitioners and we provide some tools for practitioners to use to apply and then test and critique the conceptual framework to practice (Appendices A-D)

We have four main sections to the framework as follows. In Section 2.2, we set out our main argument that a 'protective-support and supportive-protection' conceptual framework offers a broad overarching approach to inform child welfare practice. We then summarise the knowledge base underpinning this in Section 2.3. In Section 2.4, we argue that consideration of this as a process within the bio-ecological context helps to capture the multi-faceted nature of practice especially allowing for more focus on extrinsic factors that impact on the causes and responses to child protection concerns. In Section 2.5, we propose that to activate our framework further, an emphasis on the skills of networking and the use of informal and formal networks to enable specific and focused interaction between micro-meso and exo-macro systems is necessary. Throughout, we offer some suggestions for how this can be used in supervision and practice development (Appendices $\mathrm{A}-\mathrm{C}$ ). In the discussion and conclusion, we argue that the conceptual framework, while beneficial to guide discussions and case planning, remains limited because it resides mostly in the academic domain. To test and develop the framework, we argue that a practice research approach (Marthinsen and Julkunen 2012) is essential so that practitioners can consider the knowledge emerging from the conceptual work, apply and critique it in collaboration with each other and with service users. Appendix D offers guidance to inform this development. We argue that the unique contribution we make is to provide an applicable framework capable of dealing with the complex layers of child protection and welfare practice that can be used irrespective of specific models and methods of practice.

\subsection{Summary of 'Protective Support-Supportive Protection' Framework}

In McGregor and Devaney (2020), we adapted Hardiker et al.'s (1991) model of preventative practice. We used our discussion in relation to child protection and welfare in Ireland to challenge the notion of 'interface' when we refer to support and protection and suggest instead that they are complementary practices that most often go hand in hand (see also Devaney and McGregor 2017). We identified the problem that relationships between support and protection are often not integrated or, when they are, are done so in a linear way, and we wanted to offer an alternative framework that better reflects the nature of practice. We argued that while Levels 2 to 4 in Hardiker et al. denote 
different thresholds of need and risk, most families are 'in the middle' with a level of need between support and protection.

We made the case for developing Hardiker et al. (1991) to take more account of three core aspects of practice by breaking down Levels 4 and 1 and integrating Levels 2-4a. Specifically we suggested that the following levels reflect current practice:

- Levels 2-4a: These levels relate to what we referred to as 'families in the middle' who make up the majority of users of child welfare services needing support and/or protection at a point in time or over a life-time. These are families with high levels of need and/or risk concerns.

- Level 4b: Families who need more formal civic and criminal legal intervention that requires an explicit socio-legal intervention in partnership with courts and police services. While the commitment to protective support and supportive protection is still present, it is overlaid with explicitly socio-legally mandated work. This includes working in contexts where the 'potential subjectivity' (See Philp 1979; Skehill 2004; Hyslop 2018) or possibility of change in the interests of the child is outweighed by objective harmful and/or illegal behavior that requires civil and criminal legal interventions.

- Levels 1a and $1 \mathrm{~b}$ : These relate to universal services and the public, which are differentiated between formal universal services and informal natural networks and supports. We argued that more emphasis should be placed on strengthening both formal and informal aspects of these levels.

There are other threshold models that can be applied (see Connolly and Katz 2019). There are also critical warnings about the limits of a thresholds approach (Devaney 2018) and models specifically developed within family support (Dolan et al. 2006) and framed differently in other jurisdictions (see Dunst et al. 2002). In line with the United Nations Convention on the Rights of the Child, in many jurisdictions, family support and child protection are triangulated with children's rights (Gilbert et al. 2011; Merkel-Holguin et al. 2019; Connolly and Katz 2019). With reference to Daly et al. (2015), the authors acknowledge the complex differences between child welfare systems internationally but contend that one common feature throughout is evidence of 'orientation' or 'balance' between supporting children, youth, and families, and child protection. Our argument is that a commitment to a process that prioritizes doing protective work supportively and doing supportive work protectively helps to bring together distinct practices between 'support' workers and 'protection' workers across all threshold levels. The majority of intervention involves explicit support and protection practice vacillating often between high levels of need and harm (Levels 2 to $4 \mathrm{a}$ ). This interconnects with the more legal and criminal context of the child that we called $4 \mathrm{~b}$, and with the wider public and universal services outside of the specific child and family agency (formal and informal at Levels 1a and $1 b)$. The child protection worker has to have the skills, knowledge, and values to span this full scale of support and practice, within a socio-legal context. We propose that this framework, as developed here using ecological and network theories, can provide greater scope than heretofore available, to inform supervision discussions about child protection practice and skills development.

\subsection{Knowledge Base Informing the Framework}

We come from the position that child protection practice is essentially a practice of mediation in the social. As Parton has charted, child protection has evolved over time being influenced in the mid-20th century by a focus on medico-social discourse (e.g., the battered baby syndrome) to socio-legal discourses in the advancement and development of child care legislation (Parton 1991). In the past 50 years, at a varying pace in different contexts, a welcome legal emphasis in child protection has been the shift from intervention where there is evidence of harm to intervening when there is evidence of likelihood or risk of harm. This focus on risk is reflective of wider societal developments (see Beck 1992). One example in Ireland relates to the introduction of legislation to intervene on the basis of risk of significant harm under the Child Care Act 1991 which reformed the Children Act 1908 which only allowed for intervention where evidence of harm existed. This legal limit, linked with 
the family-centric (if married) constitution, was directly seen to have affected failure to intervene in one of the first child abuse inquiries in Ireland, the Kilkenny Incest Investigation (Mc Guinness 1993). However, while we should welcome this greater scope of intervention for protecting children at risk-in the sense that it gives more scope to protect a child from harm - it also brings with it increased anxiety and pressure as it links with theories of chance and probability which by nature, do not have certainty. A focus on risk brings with it the need for advanced skills, knowledge, and values for child protection workers to be able to predict the future and make judgments not only on what has happened but what is likely to happen (Wilkins and Forrester 2020). Assessing, managing, and balancing risk are key influential factors in decision-making in child protection (McCafferty and Taylor 2020), and living with uncertainty is easier to say than do when one is engaged professionally and empathically with children, young people, and families on a one-to-one basis. Rather than becoming more comfortable with living with a risk environment, there is evidence in Ireland of increasingly risk averse policy making in the areas, for example, of retrospective disclosure of child abuse (Mooney 2018) and responding to past practices in institutions such as mother and baby homes (Buckley and McGregor 2019).

It was indeed the over-emphasis on risk also seen in England that led to the review of child protection triggered by the Baby P case (Munro 2011). This created a re-emphasis on relationships in child protection practice as a means of ensuring that where there is the need for regulation and risk management this is done in a way that emphasizes the importance and centrality of doing so through relationships (Ruch et al. 2017; Ferguson et al. 2020). A stronger emphasis on relationships, and attachment in particular, emerged also in Ireland after the Roscommon Child Abuse Inquiry (Gibbons 2010) which found that observations of disorganized attachment were mistaken as strong attachment. This strongly influenced decision making about the continuum of good-enough conditions at home versus removal of children into a care setting. In some other jurisdictions, the emphasis on risk has emerged through changing social conditions (e.g., Harrikari and Rauhala 2019), while in others-for example, the Pacific regions-other core principles like relationships, love, and humility (Mafile'o 2019) are the leading discourses of practice.

One of the means towards improving relational practices is to focus on the use of family support principles, practices, and values in child protection. It is interesting to note that while we have some good examples of publishing relating to child protection and family support (e.g., Parton 1997; Corby 1998; Fargion 2014; Devaney 2011; Devaney 2017; Devaney and McGregor 2017; Pinkerton et al. 2019), this area is surprisingly under-developed given the duality of support and protection inherent in child welfare practice. Inexplicably, parenting support is also often seen as separate policy and practice orientation (Connolly and Devaney 2018). As mentioned earlier, services in Ireland are organized and divided between child protection (intake, assessment and intervention, children in care, fostering) and family support services although there has been greater integration in recent years. Family support practitioners may include professional social workers but are more likely to be social care trained (Devaney and McGregor 2017). A Master's degree in family support studies exists at the National University of Ireland, Galway (Devaney 2015) and otherwise, child protection resides primarily in social work Degree and Master programs. Youth and Community Work are separated as distinct qualifications and activities and graduates tend to be employed more within the voluntary and third sector.

Based on this knowledge base, we argue that greater integration of family support and child protection conceptually and practically is essential in child protection practice. It seems to align with a constant in child protection practice of mediating in the social (Parton 1991; Philp 1979; Skehill 2004; Hyslop 2018). We favor the model as it shows capability of application to a wider range of contexts which will have different orientations and approaches to balancing between support and protection. However, without a further device to critically analyze how support is perceived and how protection is legislated for, it may prove difficult to apply as an additional framework to existing practice models. The diversity of context for Ireland alone requires this nuanced approach. In order to provide a 
framework to capture and develop this complexity, we think that the bio-ecological model offers an appropriate next step as discussed below.

\subsection{Using Bio-Ecological Model to Develop Further a Practice and Supervision Framework}

\subsubsection{Brief Overview}

Bronfenbrenner (1979) introduced an ecological model for understanding human development that has gained wide appeal in many fields, including social work and social care. Over time, Bronfenbrenner focused more on the bio-ecological (Bronfenbrenner and Ceci 1994; Bronfenbrenner and Morris 1998, 2006) and this is the specific framework we have chosen to apply here. While application of the ecological model is not without its critics (see Tudge et al. 2009), it does offer a way to deepen the 'person-in-environment' relationship and serves as an excellent tool for mapping influences and planning interventions. The ecological model has been influential in informing child protection and welfare assessment frameworks and family support models of practice for decades (e.g., Jack 2000). In Ireland, recent adaptations of the ecological model include a study on child protection decision making (McCormack et al. 2020) and outcomes for permanence and stability for children in care (Devaney et al. 2018).

The model is based on PPCT-person, process, context (micro, meso, exo, and macro), and time (chrono and moments). The focus is on interactions and 'proximal processes.' It is this interactive component that we find most useful as a guide for practice development and supervision. It starts with person, then process; in this instance, this is mediating protective support and supportive protection. This is followed by context which relates to the levels of micro, meso, exo, and macro. We talk about time which adds the chrono level—trends in time, for example—and some discussion on time itself. Appendix A provides a sample table that practitioner and/or supervisor can use to frame critical discussion on themes pertinent under each of the headings briefly discussed below.

\subsubsection{Person(s)}

One of the major contributions from Ireland to child and family practice has been the introduction of the Meitheal practice model (Rodriguez et al. 2018). This placed the child at the center of the process and requires that all planning and decision making is influenced by this positioning. Current work relating to the day-to-day experiences of social work such as Winter and Cree (2016) and Ferguson et al. (2020) shows the intensity of interactions at a person-to-person level for worker and service users. By applying the P to the PPCT in the protection-support framework, we emphasize the distinctiveness of practice starting at the micro with the person and practitioner's own personhood and self-awareness in this process. This argument is further developed below in the discussion on the micro level

Thinking about the person should also be applied to the worker. It is now well-established that child protection and welfare work, by its nature and intensity, can lead to burnout and vicarious trauma for the practitioner involved. In Ireland, Burns (2011) has highlighted the factors that impact on staff retention in child protection and how they might be addressed. A balance in supervision and support between building resilience and strength to withstand the challenges of the work is required, while also recognizing the need to address the wider impact on persons in their work environment such as lack of resources, an over-focus on business processes, a lack of awareness of impact of dealing with traumatic issues, and denial of organizational factors thus leading to a blame culture on a worker deemed not to be 'coping.' Emotional intelligence needs to be balanced with emotional support similar to the arguments made in Australia regarding the role of supervision in creating safe space for practitioners (McPherson and MacNamara 2017). 


\subsubsection{Process}

The importance of process, relationships, risk management, and mediation in the social have already been discussed. In this case, the process is engaging through a protective support and supportive protection framework. The specific country, agency context, and existing practice models must determine the scope of intervention. For example, Signs of Safety, developed in Australia (Turnell and Murphy 2017) has come to influence many jurisdictions including Ireland and it is now the favored child protection practice model in which many relevant practitioners are trained. Signs of Safety focuses on strengths and safety planning and shares principles with support and prevention models such as Meitheal in Ireland (Malone et al. 2018). We argue that whatever the specific model being used, a continuity framing practice as protective support and supportive protection offers a way to combine important practices of family support and socio-legal interventions that works with the majority of service users. Activating this complex process is aided, we suggest, by considering the different levels of context as outlined below.

\subsubsection{Context}

In this framework, context can be used to differentiate cause and focus of a presenting child welfare concern from micro through to the macro level (see Bywaters et al. 2018). Context can also be used to decide on levels of intervention from focused individual and direct work with children, youth, parents, and families, to wider policy and political engagement (Marston and McDonald 2012). Appendix A maps how this can be used in supervision and practice skills development. For example, at the micro level, this overlaps with reference to person above and encourages a focus in the interactions from the micro system into the wider meso/exo and macro level. Micro interactions encompass a range of intrinsic (e.g., mental health and wellbeing, personality, attachment, trauma) and extrinsic (personality, relationships, home, siblings) dimensions connecting strongly with the surrounding meso level - the inner circle of micro relations. Awareness of the nature of family relations within and between individuals and cultures is crucial here to maximize the potential for close partnership working with families appropriate to the specific cultural contexts of engagement (Ruch et al. 2017). Meso interactions can include both informal/natural relations (within family, friends, extended family, local community worker) and formal individual relations (e.g., with school teacher, resource worker, individual social worker(s), police, solicitors). The connection between micro to meso goes outwards also to exo, towards the formal structures from which many of the formal relations come from (e.g., the social work agency, child welfare office, school, solicitors office, legal aid services, police service) as well as the wider community and extended family environment (welfare office, community group, family resource centre, early years provider). It is often at this level of interaction that detailed actions relating to individual cases can be difficult to break down. Appendix A should be especially useful for developing interactions with the wider exo and macro level.

For example, increasingly in Ireland, better structures exist to engage at the exo level of practice, such as local child and family support networks and children's services committees that bring together relevant personnel from statutory, voluntary, and third sector domains to work together (see Rodriguez et al. 2018). The child welfare organization itself has expanded its teams and structures as well as related training and policy development (Tusla 2020). The macro level then denotes the wider policy and legal contexts that shape people's interactions with the system and with wider society.

Another major challenge presently in the wider context of the Irish system is how to connect government department of Department of Children and Youth Affairs with related departments of welfare, housing and the environment, justice, and health to address wider social issues affecting individual service users (McGregor and Gabhainn 2018). In Ireland, these presently include increases in child poverty, family homelessness, inadequate child and youth mental health services, and inadequate services for families seeking asylum. There is also a disconnect between disability and child protection services and evidence of discrimination and inequity experienced by many individuals and groups in Ireland including Travellers, (European Commission Against Racism and Intolerance (ECRI) 2019), 
persons with disability (Flynn 2020), asylum seekers, and unaccompanied minors (Ní Raghallaigh 2018). Another major macro and exo level challenge relates to the Irish legal system. As evidenced in the work of Coulter $(2015,2018)$ and Halton et al. $(2018)$, there are significant issues arising with regard to knowledge and understanding of child welfare and family relations within the legal system.

The key to using the bio-ecological model effectively in this context is to use it as a visual and adaptable mapping tool with children, youth, and families to pinpoint both causes of concern and focus for intervention. This can also be used in supervision to inform case review and planning. Strengths, risk factors, and plans for intervention denoted in approaches like Signs of Safety, mostly focused on the micro-meso level (see Keddell 2014), can be further strengthened with explicit and sophisticated use of the ecological or similar system level models by strategic and collaborative usage to ensure the target of concern is more carefully considered. The scope to identify concrete actions at exo and macro level is especially important here.

\subsubsection{Time-Chrono}

The chrono level is usually denoted as a fifth concentric 'circle' in the ecological model. This refers to trends and changes in society. For example, the influence of digital and online platforms is changing the nature of risk for children and potential ways to address. Other important chrono factors in Ireland include the introduction of stronger children's rights into a traditional Parsonian and Catholic family-favoring constitution and the recent passing of a marriage referendum to allow same-sex couple marriages. Travellers in Ireland, our indigenous ethnic minority, who continue to experience over-representation in child protection and care statistics and experience ongoing racism and discrimination have recently (and finally) received recognition as a distinct ethnicity, thus allowing more scope to use rights and legal based approaches to address the ongoing discrimination in this area. As well as trends, time is also about moments and connects, in our view, to processes and relationships. Ample evidence abounds that tells us that people's direct experience of worker interventions strongly influences their positive or negative perceptions of the child welfare and protection system (see, for example, Buckley et al. 2011).

\subsubsection{Reflections on the Bio-Ecological Framework}

Recent developments in Ireland offer a welcome opportunity for greater collaboration across different practices, disciplines, and professions from micro to macro levels. But there are notable challenges to implementing a framework of protective support and supportive protection that we have advocated for here. These relate especially to the context level from micro to macro. Here the key challenge is to intervene at the right point (threshold) from the viewpoint of child, youth, and family. We have argued that most child protection and family support happens with 'families in the middle.' Child protection and welfare workers are also often in the middle-supporting and protecting-while interacting with the wider context at Levels $1 \mathrm{a}$ and $1 \mathrm{~b}$ and Level $4 \mathrm{~b}$. While the ecological model is well developed as an assessment and mapping tool, we have argued here for the need for a more dynamic engagement with the PPCT model (Bronfenbrenner and Morris 1998, 2006; Bronfenbrenner and Ceci 1994) and its use as a supervision and practice development tool. Taking into account this framework, practitioners need a wide range of skills to identify and protect and support directly through therapeutic or socio-legal work as well as indirectly through agency and organizational structures and related organizations. Excellent ability to work collaboratively with the public and universal services, to mediate support and protection with families who come into the system, and to confidently and assertively engage more explicitly within the socio-legal domain and work with police and courts to address the injustice of child abuse and neglect are required. Additionally, more explicit attention to factors at exo and macro level issues are urgently needed.

While the bio-ecological model is very useful to map and plan assessment, interventions, and evaluations at the different levels through supervision, alone, we think it is still too broad and general to help focus individual practices sufficiently. In particular, it does not address the question 
of how workers can influence socio-structural exo and macro factors while also maintaining their micro-meso focus on the child at the center. One way forward, we suggest, is to apply more reflection on network theory and practices of networking in supervision and practice development to activate the framework further.

\subsection{Networks and Networking in Child Protection}

Social network theory has been applied across many disciplines including management and psychology (see, for example, Kadushin 2012). Social network theory has also been a familiar feature of social work and social care for many decades (see, for example, Sharkey 1989; Timms 1990) and has been influential in many fields of practice, including disability and working with older people. It is important to distinguish between networks as formal and informally occurring structures and networking as a skill and a practice. Social network theory has wider applicability links to theories relating to social capital as described by Bourdieu (see Houston 2019) and social support theory (Devaney and Dolan 2017).

Here, we embrace the recommendations of Frost (2017) who argues that social work generally needs to move from being a siloed profession and towards a more networked approach to practice as a core feature of practice, and we support this general assertion. We argue that this networked approach will enable practitioners working to protect and support children, young people, and families to more strategically target and address extrinsic factors in particular that impact on children's safety and wellbeing. Frost focused on the practices of co-location and inter-disciplinary work using the area of CSE (child sexual exploitation) which relates to one dimension of networking. This type of networking is crucial but we also argue that, in child protection practice, the scope can be wider with regard to use of network theory, structured networks, and ideas about networking (see, for example, Kadushin 2012), alongside social network interventions with children, young people, and families. We suggest that this emphasis on networks enables the location of specific network activity between workers and service users (micro-meso) and exo and macro 'nodes' to address some of the extrinsic factors that have such a great impact on child protection and welfare practices (see Appendix B). We suggest that there needs to be a range of approaches taken. For example, the newly introduced version of Barnuhus model for child sexual exploitation in Ireland, the One House project, provides a similar opportunity to multi-disciplinary working as Frost (2017) explored in his research. There is strong evidence to support the situation of all professionals involved in Child Sexual Abuse (CSA) including medical, legal, forensic, psychological, police, and social work services (see Dolan and Caroline 2020). In relation to Tusla, child protection and welfare intake services (for example inter-disciplinary and inter-agency relations) developed through networking are also essential given that the child and family agency relies heavily on voluntary services commissioned to deliver key early intervention and prevention programs. Using Appendix B, a network plan can be used to target the relevant organization, formal network, campaign group, service user group, and so on to engage with. Appendix $C$ provides an illustrative list of options to be considered in an Irish context.

An under-utilized network action is the collation of data from casework individually and collectively to influence interactions. Practitioners in child protection can get even closer than ethnography studies to be able to identify and communicate with confidence the nature and appropriate responses needed in individual micro-meso contexts. The expanding range of opportunities for Irish child protection workers to gain support in relation to evidence-based practice, pursue doctoral research in practice, write research, and engage in practitioner research partnerships is crucial. Such practice research activities need to continue to be supported by the organization and the local academic universities and colleges that can support the creation of greater visibility of child protection practitioner expertise and the use of this to continue to deepen and build our network of knowledge to inform future theory, practice, and policy developments (see McGregor 2019, Appendix D).

Networking provides a tool to address both micro-meso and exo-macro level concerns in a systemic way. This begins with practitioners with roles in family support and child protection working together 
to achieve better outcomes for children and families (see, for example, Devaney and Dolan 2017; Ferguson et al. 2020). By practitioners involved in family support being highly skilled in child protection matters, there is a great opportunity for earlier intervention and prevention. Greater ability to 'hold' and 'manage' risk within a supportive context - with support as needed from child protection colleagues-should prevent some families meeting a threshold for referral into the child protection and welfare aspect of the services under the Irish guidance, Children First 2017, for reporting and address concerns about child abuse and neglect. Generally, as we argued in Devaney and McGregor (2017), practitioners involved in child protection and family support can engage collaboratively and create effective networks and relationships together in training, practice, and supervision processes. We also suggest that networking is best achieved from the micro-meso level outwards and suggest a revised visualization of this relationship in Appendix B. As shown in Appendix C, a number of potential network nodes can be targeted for action through supervision and practice development.

To enable further reach towards engagement at Levels $1 a$ and $1 b$, broadening of networks with those working more closely with the public in communities, localities, and early intervention and prevention services will enhance their ability to support those who become involved with child protection to engage. Also, the better the network between the early intervention and prevention services, universal services, and child protection, the more likely we are to prevent referrals in the first place, build trust in the system, and enable people to be more confident and less afraid of seeking statutory help with parenting and family support (see Daro 2016, 2019). Use of opportunities such as public awareness activities to run joint events can enhance networking potential and delivery of common messages to the public about family support and child protection. We know from current research (McGregor et al. 2018) that the public still views the statutory child and family agency as mostly about child protection and children in care, but this is beginning to change (McGregor and Gabhainn 2018). Effective networking and support between child protection workers and their wider statutory, voluntary, formal, and informal networks workers has huge further potential (as it is happening) to address public and media misperceptions about the primary function of the system to intervene against parents' wishes or in an overly anti-family way ( $\mathrm{O}^{\prime}$ Connor et al. 2018). This perception links best with what we have called the Level $4 \mathrm{~b}$ aspect of practice. While this represents a minority of cases-most families are between levels $2-4 a-i t$ is important to encourage greater awareness for those working outside of child protection of the impact on persons working with some severe and shocking cases of abuse and the need for a robust child and youth centered justice approach to address this.

A particular emphasis needs to be placed on how to use networks and engage at the exo and macro level. While wider engagement with exo and macro factors will not address the range of child abuse and neglect issue that are contained within micro-meso level interactions, it will address significant portions of neglect, child welfare, and related child protection concerns (Bywaters et al. 2018; Morris et al. 2018). Greater partnership work with families to strengthen their own social network, avail of potential social capital in their community (e.g., local advocacy group, local politician) can enhance and add to partnership and collaborative working (Rodriguez et al. 2018; Brady et al. 2020). Social network practice is core to traditional social work and social care and can be drawn on more explicitly to guide child protection and support practices. It can also include engagement through formal structures for childcare networks to reach politicians and policy makers.

Reflecting back to the broad protective support and supportive protection framework, in all of this work, the scope of child protection practice from informal family self-governance through universal and targeted services, needs to be borne in mind. Through taking a networked professional approach, we have greater capacity to differentiate the wider social issues that are contributing to, if not creating, many child welfare referrals. This then leads to greater scope to intervene intensely, through protective support and supportive protection at the micro and meso level on the individual issues that lead to child protection and welfare concerns. Developing a stronger focus on networks and networking in social work will not eradicate child protection concerns but it should reduce those referred and lead to greater prevention and early intervention. This will not replace 'high level' $4 \mathrm{~b}$ concerns but 
it could help to re-orientate and reduce harm through better support and respect to the dignity of parents, youth, children, and communities. Differentiated responses require differentiated networking. For Irish child protection and welfare workers, this means building networks with universal and community services where appropriate (e.g., connecting with local schools and building relations with teachers, knowing the GP service of the area), strengthening networks of support and protection that are engaged with most families 'in the middle,' and engaging in more targeted socio-legal networking through collaboration and joint training with those involved in the legal system (e.g., police, solicitors, guardian ad litmus).

Not all workers can or should attempt to extend their networks across all domains. Supervision and practice development can be used to target nature and level of interventions at individual, team, and organizational levels using Appendices B and C for example. Of course, such a networking approach is not a panacea. Turba et al. (2019) for example, based on a study of professional and organizational networks in child protection in Norway, discuss the barriers to professional networks. They argue that the professional and bureaucratic authority of child protection workers and managers, operating within a highly structured context, may make it difficult as this can cause "irritation and anxiety among their co-actors, resulting in the perception of poor collaboration" (p. 1; see also Herrera-Pastor et al. 2019).

If everyone perceived networking (informally and through formal structures) as core to business, then by diffusion, as Kadushin (2012) explains, it is possible to foresee a culture change towards child protection becoming a more networked activity. We argue that an integrated rather than an interfacing conceptualization of family support and child protection that can map interactions at different levels is essential to enable such a development. Diffusion implies that no one person has all of the answers; no one can do it all but we can all do something. There is capacity to gain belief and confidence in addressing what seem like wicked, un-addressable, or toxic issues not as one whole issue but through a multitude of individual networked practices targeting different levels depending on the nature, cause, and response to child protection concerns. In doing this, the focus has to stay on the personhood of the child/young person at the center of concern and the relational aspects of practice. Child protection workers alone cannot, in addition to this, take on the enormous 'big picture' of the exo and macro factors too. As much as child protection workers need to extend their networking skills to interact more with the exo and macro level as core to their work, so too do colleagues and individuals working in community, universal, and early intervention, and family support services need to network into child protection to support and sustain the work.

\section{Discussion and Conclusion}

In this paper, we have argued that the process and practice of protective support and supportive protection can be framed within a broader bio-ecological framework. To activate and specify interactions, we propose a networking approach. We suggest that in addition to the core practices of sharing information, collaboration, consultation, and full participation (Bell 1999) we can add facilitation of networking with formal and informal systems as another important participatory practice. We have argued that key to operating within a wider ecological framework, with an emphasis on networking for the reasons discussed above, a shift in thinking about the relationship between support and protection as 'interfacing' towards seeing them as 'integrative' is essential. We have sought to offer a way to do this by proposing and developing our 'protective support and supportive protection' model.

Our commentary implies a high level of expectation from child protection workers' skills. This includes ability to directly intervene therapeutically and supportively, to network, to advocate, to challenge, to confidently engage with the courts and police, and to contribute to public understandings of child protection. As a mainly conceptual paper, the next step for this framework is to ask practitioners to progress it further. In using it as a supervision and practice development tool, data and observations could be collated through embedded practice research. The framework so far can be described as 'Mode 1' knowledge production (Rasmussen 2012) derived from traditional scientific hierarchies 
of knowledge produced through universities and peer review (see also, McGregor 2019). There is now a need to advance the work within a 'Mode 2' framework which refers to an approach where knowledge production is broadened into the field and led by practitioners and service users who apply and experience the knowledge application in practice (Rasmussen 2012; Uggerhoj 2012; Satka 2020). As Marthinsen (2012) argues, this does not mean a rejection of more traditional conceptual approaches like we have used here. Rather it is about developing a relationship with theory to practice whereby practitioners can respond to and speak back to frameworks through incorporating practice research into supervision and practice development (see for example Appendix D). As Rasmussen (2012) argues, practice research can be characterized as a type of knowledge production, referred to as Mode 2, which sits alongside and compliments, rather than displacing Mode 1 . At the same time, Mode 2 brings an essential value unattainable through Mode 1 theorization alone as detailed ore in Appendix D. It is also an approach that supports a networked approach:

"When practitioners form networks, they can develop the perspectives, concepts and categories that are relevant to their needs .... By generating knowledge gained from different perspectives, such research would be reflexive and well-grounded in specific practices rather than presuming to produce the one right answer to address one pre-described category of problems or methods" (Rasmussen 2012, p. 47).

Thus, we conclude with a humble recognition that our contribution is limited without an essential next step of practitioners and those they work with critically engaging in dialogue, testing, application, critiquing, and recreation of the framework. With this addition, the framework has potential to be transformative in an overarching way to make sense of the complex relationship between child protection and family support informing micro to macro level practice and policy developments.

Author Contributions: All authors contributed equally to this paper. All authors have read and agreed to the published version of the manuscript.

Funding: This research received no external funding.

Conflicts of Interest: The authors declare no conflict of interest. 


\section{Appendix A. Sample Discussion Tool for Practice Development and Supervision 1: Mapping Practice with the Bio-Ecological Framework}

Note: In the diagram below, these levels are all inter-acting and inter-dependent as reflected in the circular concentric presentation. We provide an adapted version of the ecological model we used for children in care as an example (Devaney et al. 2018). Practitioners should draw their own models that reflect the nature and dynamics of interventions best.

\begin{tabular}{|c|c|c|c|c|}
\hline \multicolumn{2}{|c|}{ Bio-eco Level } & $\begin{array}{l}\text { Issues for Specific } \\
\text { Practice, e.g. }\end{array}$ & $\begin{array}{c}\text { Issues for Own Professional } \\
\text { Development }\end{array}$ & $\begin{array}{l}\text { Skills/Values } \\
\text { Comment }\end{array}$ \\
\hline \multicolumn{2}{|c|}{ Person } & E.g., impact of abuse & $\begin{array}{c}\text { E.g., empathy } \\
\text { impact on self - self-care }\end{array}$ & $\begin{array}{l}\text { Balancing therapeutic } \\
\text { and socio-legal skills }\end{array}$ \\
\hline \multicolumn{2}{|c|}{ Process } & $\begin{array}{l}\text { What level of support and } \\
\text { protection needed }\end{array}$ & $\begin{array}{l}\text { Map own approach to protective } \\
\text { support and supportive protection }\end{array}$ & $\begin{array}{c}\text { Balancing } \\
\text { assertiveness and } \\
\text { supportive skills }\end{array}$ \\
\hline \multirow{3}{*}{ Context } & Micro & Quality of own network & $\begin{array}{l}\text { Mapping individual context with } \\
\text { child/young person or parent }\end{array}$ & $\begin{array}{l}\text { Empathy, observation, } \\
\text { confidence to draw } \\
\text { and use maps }\end{array}$ \\
\hline & Meso & $\begin{array}{l}\text { Relationship with social } \\
\text { worker }\end{array}$ & $\begin{array}{l}\text { Awareness of power of } \\
\text { interactions between meso-micro }\end{array}$ & Mediation skills \\
\hline & Macro & $\begin{array}{l}\text { Experience of inadequate } \\
\text { housing }\end{array}$ & $\begin{array}{c}\text { What resources has individual got, } \\
\text { e.g., local politician. } \\
\text { What network node, e.g., ask } \\
\text { manager to engage with Children } \\
\text { and Young People's Services } \\
\text { Committees (CYPSC)/local } \\
\text { housing department }\end{array}$ & $\begin{array}{l}\text { Critical awareness of } \\
\text { issues of housing and } \\
\text { link to welfare needs }\end{array}$ \\
\hline Time & Chrono & Impact of online bullying & Staff shortages and limited time & $\begin{array}{l}\text { Ability to upskill to be } \\
\text { aware of new trends } \\
\text { and challenges }\end{array}$ \\
\hline
\end{tabular}

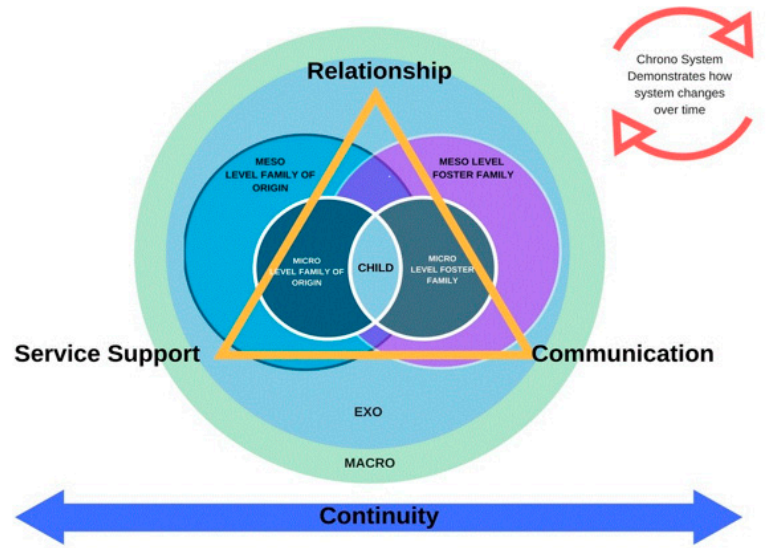

Knowledge Sources: Notes

Research Practice Evaluation: Notes 
Appendix B. Sample Discussion Tool for Practice Development and Supervision 2: Networking

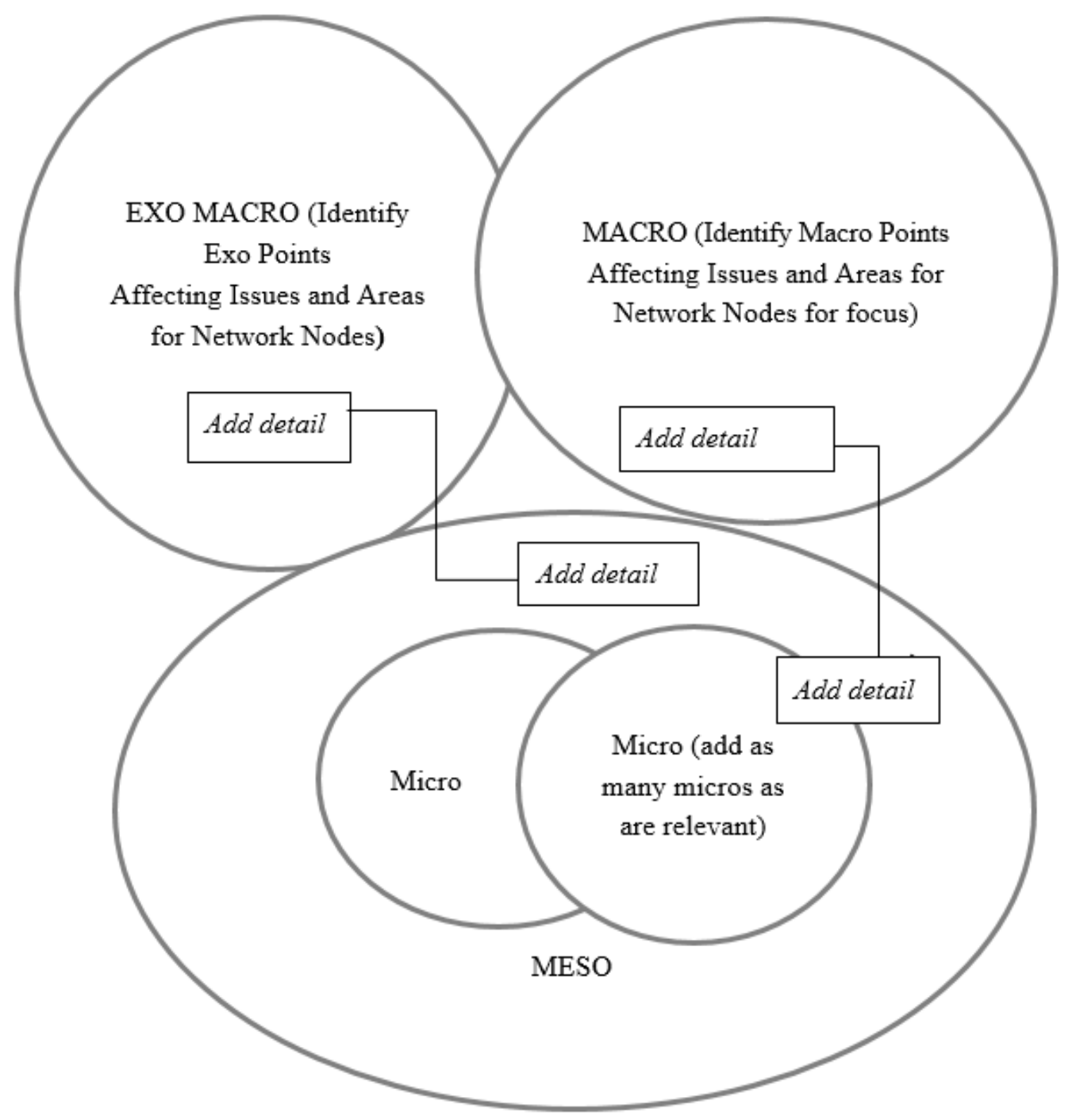




\section{Appendix C. Sample Networking Nodes to Target Networking Interactions}

\begin{tabular}{|c|c|}
\hline Node & \\
\hline Formal Structures for Networking & $\begin{array}{l}\text { In Ireland, two types of network operate in relation to child and } \\
\text { family services: } \\
\text { Child and family support networks (CFSNs) support the } \\
\text { provision of accessible and integrated supports for families by } \\
\text { taking a localized, area based approach to coordinating services. } \\
\text { A number of CFSNs can operate in any given geographical area } \\
\text { depending on population density, levels of need, and service } \\
\text { provision (exo level). } \\
\text { Children and young people's services committees (CYPSC's) are } \\
\text { responsible for securing better outcomes for children and young } \\
\text { people in their area through more effective integration of existing } \\
\text { services and interventions. Their age remit spans all children } \\
\text { and young people aged from } 0 \text { to } 24 \text { years and there is one in } \\
\text { every county in Ireland (exo level). }\end{array}$ \\
\hline Children's Participation Strategy & $\begin{array}{l}\text { In line with the children's participation strategy and training } \\
\text { available relating to this, look for examples of where children } \\
\text { and young people can work with individuals and teams to } \\
\text { advocate and influence. }\end{array}$ \\
\hline Organizational Data Sources & $\begin{array}{l}\text { Tusla reports quarterly regional and national performance data. } \\
\text { Keep up to date with trends in your region and use the data to } \\
\text { support your networking practices. }\end{array}$ \\
\hline Campaign Groups & $\begin{array}{l}\text { Link in with relevant campaign groups to ask for assistance in } \\
\text { raising issues like your observed impact of homelessness on } \\
\text { families you work with, your evidence from practice regarding } \\
\text { impact of poverty on school attendance; e.g. Children's Rights } \\
\text { Alliance, Barnardos, Irish Society for for the Prevention of } \\
\text { Cruelty to Children (ISPCC). }\end{array}$ \\
\hline Targeted Services & $\begin{array}{l}\text { Find the most relevant organization that addresses the issues } \\
\text { arising in your practice, such as local and national Traveller } \\
\text { movements, Empowering People in Care (EPIC) relating to } \\
\text { children in care and leaving care, Support groups in relation to } \\
\text { asylum seekers and refugees }\end{array}$ \\
\hline $\begin{array}{l}\text { Interagency/multi-disciplinary } \\
\text { training/learning opportunities. }\end{array}$ & $\begin{array}{l}\text { Engage in any available opportunities to attend cross } \\
\text { agency/multi-disciplinary learning or training events in your } \\
\text { area. These can be face-to-face/online. Local third level } \\
\text { institutions may provide open access seminars, conferences, and } \\
\text { training events, and many national organizations (e.g. } \\
\text { Barnardos) provide on-line training events. }\end{array}$ \\
\hline
\end{tabular}


Appendix D. Guide for Practice Researchers Testing the Application of the Framework for Supervision and Practice Development (Adapted from Marthinsen E. and Julkunen, I, 2012 Practice Research in Nordic Social Work: Knowledge Production in Transition)

- "Practice research involves curiosity about practice" (Salisbury statement on practice research in Marthinsen and Julkunen (2012, p. 194)).

- Practice research is not a method in itself, it is an approach to research led by practitioners. It can involve a range of methods depending on the objective and planned outcome of the research.

- While a range of different methods of evaluation can be used, practice research tends to orient towards multi-methods, single case studies, analysis involving reflective and narrative interpretations, and ethnographies (see Julkunen 2012).

- Practice research can be through partnerships between universities and agencies; practitioner led research, and/or practitioner and service user partnership research.

- Practice research requires the same rigor as other forms of research but tends towards a more interactive and collaborative rather than a hierarchical model (see Julkunen 2012).

- The role of the researcher in practice research is similar to that of an academic researcher: As a change agent. The practice researcher tends towards reflections through evaluation and internal validation often involving peer learning and evaluation (see Julkunen 2012).

- Practice research lends itself well to service user involvement in the evaluation and testing of different approaches to practice.

- Practice research, according to Julkunen, 2012, brings forth a new conceptualization of evaluation which is interested in "recovering a sense of making and participating rather than just seeing and finding" (p. 112).

- A practice research approach can be built into supervision and practice development through agreeing a method of recording how the supervision tools are used (e.g., using a narrative method) and committing to evaluating the framework with regard to its applicability to practice skills development. 


\section{References}

Bartley, Allen, and Liz Beddoe. 2018. Transnational Social Work: Opportunities and Challenges of a Global Profession. Chicago: Chicago University Press.

Beck, Uri. 1992. Risk Society: Towards and New Modernity. London: Sage.

Bell, Margaret. 1999. Working in Partnership in Child Protection: The Conflicts. The British Journal of Social Work 29: 437-55. [CrossRef]

Brady, Bernadine, Carmel Devaney, Rosemary Crosse, Leonor Rodriguez, and Charlotte Silke. 2020. The Strengths and Challenges of the YAP Community Based Advocate Model. Galway: UNESCO Child and Family Research Centre.

Bronfenbrenner, Uri. 1979. The Ecology of Human Development: Experiments by Nature and Design. Cambridge: Harvard University Press.

Bronfenbrenner, Uri, and Stephen J. Ceci. 1994. Nature-Nuture Reconceptualized in Developmental Perspective: A Bioecological Model. Psychological Review 101: 568. [CrossRef]

Bronfenbrenner, Uri, and Pamela A. Morris. 1998. The Ecology of Developmental Processes. In Handbook of Child Psychology, Vol. 1: Theoretical Models of Human Development, 5th ed. Edited by William Damon and Richard M. Lerner. New York: Wiley, pp. 993-1023.

Bronfenbrenner, Uri, and Pamela A. Morris. 2006. The Bioecological Model of Human Development. In Handbook of Child Psychology, Vol. 1: Theoretical Models of Human Development, 6th ed. Edited by William Damon and Richard M. Lerner. New York: Wiley, pp. 793-828.

Brown, Kate. 2019. Vulnerability and Child Sexual Exploitation: Towards an Approach Grounded In Life Experiences. Critical Social Policy 39: 622-42. [CrossRef]

Buckley, Helen. 2018. Editorial: Special Issue on Child Protection and Domestic Violence. Australian Social Work 71: 131-34. [CrossRef]

Buckley, Helen, Nicola Carr, and Sadhbh Whelan. 2011. 'Like walking on eggshells': Service user views and expectations of the child protection system. Child and Family Social Work 16: 101-10. [CrossRef]

Buckley, Sarah-Anne, and Caroline McGregor. 2019. Interrogating institutionalisation and child welfare: The Irish case, 1939-1991. European Journal of Social Work 22: 1062-72. [CrossRef]

Burns, Kenneth. 2011. 'Career preference', 'transients' and 'converts': A study of social workers' retention in child protection and welfare'. British Journal of Social Work 41: 520-38. [CrossRef]

Burns, Kenneth, and McGregor Caroline. 2019. Child protection and welfare systems in Ireland: Continuities and discontinuities of the present. In National Systems of Child Protection: Understanding the International Variability and Context for Developing Policy and Practice. Edited by Lisa Merkel-Holguin, John D. Fluke and Richard Krugman. Dordrecht: Springer.

Bywaters, Paul, Geraldine Brady, Lisa Bunting, Brigid Daniel, Brid Featherstone, Chantel Jones, Kate Morris, John Scourfield, Tim Sparks, and Calum Webb. 2018. Inequalities in English child protection practice under austerity: A universal challenge? Child E Family Social Work 23: 53-61. [CrossRef]

Canavan, John, Carmel Devane, Caroline Mc Gregor, and Aileen Shaw. 2019. A Good Fit? Ireland's Programme for Prevention, Partnership and Family Support as a Public Health Approach to Children Protection. In Re-Visioning Public Health Approaches for Protecting Children. Edited by Bob Lonne, Deb Scott, Daryl Higgins and Todd I. Herrenkohl. New York: Springer Publishers.

Connolly, Maria, and Ilan Katz. 2019. Typologies of Child Protection Systems: An International Approach. Child Abuse Review 28: 381-94. [CrossRef]

Connolly, Nuala, and Carmel Devaney. 2018. Parenting Support: Policy and Practice in the Irish Context. Child Care in Practice 24: 15-28. [CrossRef]

Coogan, Declan. 2017. Child to Parent Violence and Abuse: Family Interventions with Non-Violent Resistance. London: Jessica Kingsley.

Corby, Brian. 1998. Child Protection and Family Support. Tensions, Contradictions and Possibilities. Child and Family Social Work 3: 215-16. [CrossRef]

Coulter, Carol. 2015. Final Report of the Child Care Law Reporting Project. Dublin: Child Care Law Reporting Project.

Coulter, Carol. 2018. An Examination of Lengthy, Contested and Complex Child Protection Cases in the District Court. Dublin: Child Care Law Reporting Project. 
Daly, Mary, Rachel Bray, Zlata Bruckauf, Jasmina Byrne, Alice Margaria, Ninoslava Pećnik, and Maureen Samms-Vaughan. 2015. Family and Parenting Support: Policy and Provision in a Global Context. Florence: UNICEF Office of Research, Innocenti Insight.

Daro, Deborah. 2016. Early Family Support Interventions: Creating Context for Success. Global Social Welfare 3: 91-96. [CrossRef]

Daro, Deborah. 2019. A Shift in Perspective: A Universal Approach to Child Protection. The Future of Children 29: 17-40. [CrossRef]

Devaney, Carmel. 2011. Family Support as an Approach to Working with Children and Families in Ireland. Germany: Lap Lambert Publishing.

Devaney, Carmel, and Pat Dolan. 2017. Voice and Meaning: The Wisdom of Family Support Veterans. Child $\mathcal{E}$ Family Social Work 22: 10-20. [CrossRef]

Devaney, Carmel. 2015. Enhancing Family Support in Practice through Postgraduate Education. Social Work Education 34: 213-228. [CrossRef]

Devaney, Carmel, and Caroline McGregor. 2017. Child protection and Family Support practice in Ireland: A contribution to present debates from a historical perspective. Child and Family Social Work 22: 1-9. [CrossRef]

Devaney, Carmel. 2017. Promoting children's welfare through Family Support. In The Routledge Handbook of Global Child Welfare. Edited by Pat Dolan and Frost Nick. London: Routledge, pp. 99-109.

Devaney, Carmel, Caroline McGregor, and Lisa Moran. 2018. Outcomes for Permanence and Stability for Children in Care in Ireland: Implications for Practice. The British Journal of Social Work. [CrossRef]

Devaney, John. 2018. The Trouble with Thresholds: Rationing as A Rational Choice In Child And Family Social Work. Child and Family Social Work. [CrossRef]

Devaney, John, and Trevor Spratt. 2009. Child Abuse as a Complex and Wicked Problem: Reflecting on Policy Developments in the United Kingdom in Working with Children and Families with Multiple Problems. Children and Youth Services Review 31: 635-41. [CrossRef]

Dolan, Pat, and Frost Nick, eds. 2017. The Routledge Handbook of Global Child Welfare. London: Routledge.

Dolan, Pat, John Canavan, and John Pinkerton, eds. 2006. Family Support as Reflective Practice. London: Jessica Kingsley.

Dolan, Pat, and McGregor Caroline. 2020. Social Support Empathy and Ecology: In J. Pearce Ed Child Sexual Exploitation Why Theory Matters. Bristol: Policy Press.

Dunst, Carl J., Kimberly Boyd, Carol M. Trivette, and Deborah W. Hamby. 2002. Family-oriented program models and professional helpgiving practices. Family Relations 51: 221-29. [CrossRef]

European Commission Against Racism and Intolerance (ECRI). 2019. ECRI Report on Ireland: Fifth Monitoring Report. Strasbourg: Council of Europe.

Fargion, Silvia. 2014. Synergies and Tensions in Child Protection and Parent Support: Policy lines and Practitioners Cultures. Child and Family Social Work 19: 24-33. [CrossRef]

Featherstone, Brid, Anna Gupta, Kate Morris, and Sue White. 2018. Protecting Children: A Social Model. Bristol: Policy Press.

Ferguson, Ian, Vasilios Ioakimidis, and Michael Lavlette. 2018. Global Social Work in a Political Context: Radical Perspectives. Bristol: Policy Press.

Ferguson, Harry, Lisa Warwick, Tarsem Singh Cooner, Leigh Jadwiga, Liz Beddoe, Tom Disney, and Gillian Plumridge. 2020. The nature and culture of social work with children and families in long-term casework: Findings from a qualitative longitudinal study. Child and Family Social Work. [CrossRef]

Flynn, Susan. 2020. Towards Parity in Protection: Barriers to Effective Child Protection and Welfare Assessment with Disabled Children in the Republic of Ireland. Child Care in Practice. [CrossRef]

Frost, Nick. 2017. "From "silo" to "network" profession-A multi-professional future for social work. Journal of Children's Services 12: 174-83. [CrossRef]

Gibbons, Norah. 2010. Roscommon Child Care Case. Dublin: HSE.

Gilbert, Neil, Nigel Parton, and Marit Skivenes. 2011. Child Protection Systems: International Trends and Orientations. New York: Oxford University Press. [CrossRef]

Halton, Carmel, Gill Harold, Aileen Murphy, and Edel Walsh. 2018. A Social and Economic Analysis of the Use of Legal Services (SEALS) In the Child and Family Agency (Tusla). Cork: University College Cork. 
Hardiker, Pauline, Kenneth Exton, and Mary Barker. 1991. Policies and Practices in Preventive Child Care. Aldershot: Avebury.

Harrikari, Timo, and Pirkko-Liisa Rauhala. 2019. Towards Glocal Social Work in the Era of Compressed Modernity. London \& New York: Routledge.

Herrera-Pastor, David, Juárez Jesús, and Cristóbal Ruiz-Román. 2019. Collaborative leadership to subvert marginalisation: The workings of a socio-educational network in Los Asperones, Spain. School Leadership $\mathcal{E}$ Management. [CrossRef]

Higgins, Martyn. 2017. Child Protection Social Work in England: How Can It Be Reformed? The British Journal of Social Work 47: 293-307. [CrossRef]

Holt, Stephanie, Carolina Overlien, and John Devaney, eds. 2018. Responding to Domestic Violence Emerging Challenges for Policy, Practice and Research in Europe. London: Jessica Kingsley Publishers.

Houston, Stanley. 2019. Extending Bourdieu for Critical Social Work. In Routledge Handbook of Critical Social Work. Edited by Stephen Webb. London: Routledge.

Hyslop, Ian. 2018. Neoliberalism and social work identity. European Journal of Social Work 21: 20-31. [CrossRef]

Jack, Gordon. 2000. Ecological Influences of Parenting and Child Development. British Journal of Social Work 30 : 703-20. [CrossRef]

Joy, Eileen, and Liz Beddoe. 2019. Aces, Cultural Considerations and 'Common Sense' In Aotearoa New Zealand. Social Policy and Society 18: 491-97. [CrossRef]

Julkunen, Ilse. 2012. Critical Elements in evaluating and developing practice in social work: An exploratory overview. In Practice Research in Nordic Social Work: Knowledge Production in Transition. Edited by Edgar Marthinsen and Isle Julkunen. London: Whiting and Birch, pp. 95-116.

Kadushin, Charles. 2012. Understanding Social Networks: Theories, Concepts, and Findings. Oxford: Oxford University Press.

Keddell, Emily. 2014. Theorising the signs of safety approach to child protection social work: Positioning, codes and power. Children and Youth Services Review 47: 70-77. [CrossRef]

Killion, Mary G. 2020. Family Focused Practices in Irish Mental Health. In Irish Social Worker. Dublin: Irish Association of Social Workers.

Libesman, Terri. 2004. Child welfare approaches for Indigenous communities: International perspectives. Child Abuse Prevention Issues. Australian Institute of Family Studies 20: 1-39.

Liebenberg, Linda, and Daphne Hutt-Macleod. 2017. Community Development Programmes in Response to Neo-liberalism. In The Routledge Handbook of Global Child Welfare. Edited by Pat Dolan and Nick Frost. London: Routledge.

Lonne, Bob, Deb Scott, Daryl Higgins, and Todd Herrenkoh, eds. 2019. Re-Visioning Public Health Approaches for Protecting Children. Cham: Springer International Publishing, Volume 9, ISBN 978-3-030-05857-9.

Lotty, Maria, Audrey Dunn Galvin, and Eleanor Bantry White. 2020. Effectiveness of a trauma-informed care psychoeducational program for foster carers-Evaluation of the Fostering Connections Program. Child Abuse and Neglect. [CrossRef]

Mafile'o, Tracie. 2019. Social Work with Pacific Communities. In New Theories for Social Work Practice: Ethical Practices for Working with Individuals, Families and Communities. Edited by Robyn Munford and Kieran O'Donoghue. London: Jessica Kingsley Publishers, pp. 212-30.

Malone, Patrick, and John Canavan. 2018. Systems Change: Final Evaluation Report on Tusla's Prevention, Partnership and Family Support Programme. Galway: UNESCO Child and Family Research Centre, National University of Ireland Galway.

Malone, P., J. Canavan, C. Devaney, and C. Mc Gregor. 2018. Comparing areas of commonality and distinction between the national practice models of Meitheal and Signs of Safety. Galway: UNESCO Child and Family Research Centre.

Marston, Greg, and Catherine McDonald. 2012. Getting Beyond 'Heroic Agency' in Conceptualising Social Workers as Policy Actors in the Twenty-First Century. The British Journal of Social Work 42: 1022-38. [CrossRef]

Marthinsen, Edgar. 2012. Social Work Practice and Social Science History. In Practice Research in Nordic Social Work: Knowledge Production in Transition. Edited by Edgar Marthinsen and Isle Julkunen. London: Whiting and Birch, pp. 1-26.

Marthinsen, Edgar, and Isle Julkunen, eds. 2012. Practice Research in Nordic Social Work: Knowledge Production in Transition. London: Whiting and Birch. 
McCormack, Cheryl, Marie Gibbons, and McGregor Caroline. 2020. An Ecological Framework for Understanding and Improving Decision Making in Child Protection and Welfare Intake (Duty) Practices in the Republic of Ireland. Child Care in Practice. 26: 146-62. [CrossRef]

McGregor, Caroline. 2019. Paradigm Framework for social work in the $21^{\text {st }}$ century. The British Journal of Social Work 49: 2112-29. [CrossRef]

McGregor, Caroline. 2016. Balancing Regulation and Support in Child Protection: Using Theories of Power to Develop Reflective Tools for Practice. In Irish Social Worker. Dublin: Irish Association of Social Workers, pp. 11-16.

McGregor, Caroline, and Carmel Devaney. 2020. Protective support and supportive protection for families "in the middle": Learning from the Irish context. Child \& Family Social Work 25: 277-85.

McGregor, Caroline, and Saoirse Nic Gabhainn. 2018. Public Awareness. Galway: UNESCO Child and Family Research Centre, National University of Ireland Galway.

McGregor, Caroline, John Canavan, and Patricia O'Connor. 2018. Public Awareness Work Package Final Report: Tusla's Programme for Prevention, Partnership and Family Support. Galway: UNESCO Child and Family Research Centre, National University of Ireland Galway.

Mc Guinness, Catherine. 1993. Report of the Kilkenny Incest Investigation; Dublin: Government Publications Stationery Office.

McAlinden, Anne-Marie. 2012. 'Grooming' and the Sexual Abuse of Children: Institutional, Internet, and Familial Dimensions. Oxford: Oxford University Press.

McCafferty, Paul, and Brian Taylor. 2020. Risk, Decision-making and Assessment in Child Welfare. Child Care in Practice 26: 107-10. [CrossRef]

McPherson, Lynn, and Noel MacNamara. 2017. Supervising Child Protection Practice: What Works? Cham: Springer International Publishing.

Merkel-Holguin, Lisa, John. D. Fluke, and Richard. D. Krugman, eds. 2019. National Systems of Child Protection: Understanding the International Variability and Context for Developing Policy and Practice. New York: Springer.

Mooney, Joe. 2018. Adult Disclosures of Childhood Sexual Abuse and Section 3 of the Child Care Act 1991: Past Offences, Current Risk. Child Care in Practice 24: 245-57. [CrossRef]

Morris, Kate, Will Mason, Paul Bywaters, Brid Featherstone, Brigit Daniel, Geraldine Brady, and Calum Webb. 2018. Social Work, Poverty, and Child Welfare Interventions. Child E Family Social Work 23: 364-72.

Morrison, Tony. 2010. The Strategic Leadership of Complex Practice: Opportunities and Challenges. Child Abuse Review 19: 312-29. [CrossRef]

Munford, Robyn, and Kieran O'Donoghue. 2019. New Theories for Social Work Practice: Ethical Practices for Working with Individuals, Families and Communities. London: Jessica Kingsley Publishers, pp. 212-30.

Munro, Eileen. 2011. The Munro Review of Child Protection: Final Report. A Child-Centred System. London: Department of Education.

Ní Raghallaigh, Muireann. 2018. The integration of asylum seeking and refugee children: Resilience in the face of adversity. In Research Handbook on Child Migration. Edited by Jacqueline Bhabha, Jyothi Kanics and Daniel Senovilla Hernández. Elgar: Cheltenham, pp. 351-87.

O'Connor, Patricia, Caroline McGregor, and Carmel Devaney. 2018. Newspaper Content Analysis: Print Media Coverage of Ireland's Child and Family Agency (Tusla) 2014-2017. Galway: The UNESCO Child and Family Research Centre, National University of Ireland Galway.

O'Donoghue, Kirean. 2019. Supervision and Evidence Informed Practice. In New Theories for Social Work Practice: Ethical Practices for Working with Individuals, Families and Communities. Edited by Robyn Munford and K. O’Donoghue. London: Jessica Kingsley Publishers, pp. 271-88.

Overlien, Carolina, and Stephanie Holt. 2019. Editorial: European Research on Children, Adolescents and Domestic Violence: Impact, Interventions and Innovations. Journal of Family Violence 34: 365-69. [CrossRef]

Parton, Nigel. 1991. Governing the Family. London: MacMillan.

Parton, Nigel. 1997. Child protection and family support: Current debates and future prospects. In Child Protection and Family Support: Tensions, Contradictions and Possibilities. Edited by Nigel Parton. London: Routledge.

Parton, Nigel. 2014. Social Work, Child Protection and Politics: Some Critical and Constructive Reflections. British Journal of Social Work 44: 2042-56. [CrossRef]

Parton, Nigel, ed. 2015a. Contemporary Developments in Child Protection. Vol 1 Policy Changes and Challenges. Basel: MDPI. 
Parton, Nigel, ed. 2015b. Contemporary Developments in Child Protection. Vol 2 Issues in Child Welfare. Basel: MDPI. Parton, Nigel, ed. 2015c. Contemporary Developments in Child Protection. Vol 3 Broadening Challenges in Child Protection. Basel: MDPI.

Pearce, Jenny. 2019. Child Sexual Exploitation: Why Theory Matters. Bristol: Policy Press.

Pinkerton, John, Canavan John, and P. Dolan. 2019. Family Support and Social Work Practice. In New Theories for Social Work Practice: Ethical Practice for Working with Individuals, Families and Communities. Edited by R. Munford and K. O’Donoghue. London: Jessica Kingsley Publishing, pp. 44-62.

Philp, Mark. 1979. Notes on the Forms of Knowledge in Social Work. Sociological Review 27: 83-111. [CrossRef]

Rasmussen, Tove. 2012. Knowledge production and social work: Forming knowledge production. In Practice Research in Nordic Social Work: Knowledge Production in Transition. Edited by Edgar Marthinsen and Isle Julkunen. London: Whiting and Birch, pp. 43-66.

Rodriguez, L., A. Cassidy, and C. Devaney. 2018. Meitheal Process and Outcomes Study. Galway: UNESCO Child and Family Research Centre, National University of Ireland Galway.

Ruch, Gillian, Karen Winter, Viv Cree, Sophie Hallet, Fiona Morrisson, and Mark Hadfield. 2017. Making meaningful connections: Using insights from social pedagogy in statutory child and family social work practice. Child and Family Social Work 22: 1015-23. [CrossRef]

Sapouna, Lydia. 2020. Service-user narratives in social work education; Co-production or co-option? Social Work Education. [CrossRef]

Satka, Mirja. 2020. Pragmatist knowledge production in practice research. In The Routledge Handbook of Social Work Practice Research. Edited by Lynette Joubert and Martin Webber. London: Routledge.

Sharkey, Peter. 1989. Social Networks and Social Service Workers. The British Journal of Social Work 19: 387-405. [CrossRef]

Shemmings, David, and Yvonne Shemmings. 2011. Understanding Disorganized Attachment: Theory and Practice for Working with Children and Adults. London: Jessica Kingsley Publishers.

Slettebø, Tor. 2013. Partnership with Parents of Children in Care: A Study of Collective User Participation in Child Protection Services. The British Journal of Social Work 43: 579-95. [CrossRef]

Skehill, Caroline. 2004. History of the Present of Child Protection and Welfare Social Work in Ireland. Lapmeter: Edwin Mellen.

Spratt, Trevor, John Devaney, and John Frederick. 2019. Adverse Childhood Experiences: Beyond Signs of Safety; Reimagining the Organisation and Practice of Social Work with Children and Families. British Journal of Social Work 49: 2042-58. [CrossRef]

Tanner, Denise, Rosemary Littlechild, Joe Duffy, and David Hayes. 2017. 'Making It Real': Evaluating the Impact of Service User and Carer Involvement in Social Work Education. British Journal of Social Work 47: 467-68. [CrossRef]

Tierney, Edel, Danielle Kennan, Cormac Forkan, Bernadine Brady, and Rebecca Jackson. 2018. Children's Participation Work Package Final Report: Tusla's Programme for Prevention, Partnership and Family Support. Galway: UNESCO Child and Family Research Centre, National University of Ireland Galway.

Timms, Elizabeth. 1990. Social Networks and Social Service Workers: A Comment on Sharkey. The British Journal of Social Work 20: 627-31. [CrossRef]

Tudge, Johnathan, Irina Mokrova, Bridget E. Hatfield, and Rachana B. Karnik. 2009. Uses and Misuses of Bronfenbrenner's Bioecological Theory of Human Development. Journal of Family Theory E Review 1: 198-210.

Turba, Hannu, Janne Paulsen Breimo, and Christian Lo. 2019. Professional and Organizational Power Intwined: Barriers to Networking? Children and Youth Services Review. [CrossRef]

Turnell, Andrew, and Terry Murphy. 2017. Signs of Safety Comprehensive Briefing Paper, 4th ed. Perth: Resolutions Consultancy Pty Ltd.

Tusla. 2019. Third Quarterly Performance Data Report. Dublin: Tusla.

Tusla. 2020. Available online: www.tusla.ie (accessed on 30 March 2020).

Uggerhoj, Lars. 2012. Theorising practice research in social work. In Practice Research in Nordic Social Work: Knowledge Production in Transition. Edited by Edgar Marthinsen and Isle Julkunen. London: Whiting and Birch, pp. 67-94.

Wilkins, David. 2012. Disorganised attachment indicates child maltreatment: How is this link useful for child protection social workers? Journal of Social Work Practice 26: 15-30. [CrossRef] 
Wilkins, David, and Donald Forrester. 2020. Predicting the Future in Child and Family Social Work: Theoretical, Ethical and Methodological Issues for a Proposed Research Programme. Child Care in Practice 26: 196-209. [CrossRef]

Winter, Karen, and Viviene E. Cree. 2016. Social Work Home Visits to Children and Families in the UK: A Foucaldian Perspective. British Journal of Social Work 46: 1175-90. [CrossRef] 